\title{
PENGARUH STRUKTUR MODAL, LIKUIDITAS, DAN UKURAN PERUSAHAAN TERHADAP KINERJA KEUANGAN PADA PERUSAHAAN MANUFAKTUR SUBSEKTOR KEPERLUAN RUMAH TANGGA YANG TERDAFTAR DI BURSA EFEK INDONESIA (BEI) PERIODE 2014-2018
}

\author{
Petty Arisanti \\ Dosen Universitas Kahuripan Kediri \\ E-mail: arisantipetty@gmail.com
}

\begin{abstract}
Penelitain ini bertujuan untuk mengetahui pengaruh dari struktur modal, likuiditas, dan ukuran perusahaan terhadap kinerja keuangan perusahaan sektor manufaktur subsektor keperluan rumah tangga yang terdaftar di Bursa Efek Indonesia periode 2014-2018. Variabel yang digunakan untuk mengukur struktur modal adalah debt to equity ratio (DER), variabel likuiditas diukur dengan current ratio (CR), dan ukuran perusahaan dilihat dari total penjualan. Variabel yang digunakan untuk mengukur kinerja keuangan perusahaan yaitu return on equity (ROE). Populasi penelitian ini adalah perusahaan sektor manufaktur subsektor kosmetik dan keperluan rumah tangga yang terdaftar di BEI Periode 2014-2018 dengan total 6 perusahaan. Dengan menggunakan metode purposive sampling diambil sampel 4 perusahaan. Teknik analisis yang digunakan adalah analisis regresi linier berganda dan uji hipotesis dan juga dilakukan uji asumsi klasik yang meliputi uji normalitas, uji multikolinearitas, uji heteroskedastisitas dan uji autokorelasi, dengan tingkat signifikansi alpha 5\%. Hasil penelitian menunjukkan bahwa variabel struktur modal (DER) memiliki pengaruh signifikan terhadap ROE. Variabel likuiditas (CR) tidak berpengaruh terhadap ROE, sedangkan variabel ukuran perusahaan memiliki pengaruh yang signifikan terhadap ROE. Kata kunci : Debt to equity ratio (DER), current ratio (CR), ukuran perusahaan, total penjualan, return on equity (ROE).
\end{abstract}

\section{Latar Belakang}

Modal kerja yang digunakan suatu perusahaan dapat menjadi penunjangdalam kegiatan operasional perusahaan untuk meningkatkan profitabilitas. Industrimanufaktur merupakan industri yang banyak diminati oleh investor untukberinvestasi.Industri kosmetik dan keperluan rumah tangga saat ini merupakansalah satu industri yang sedang mengalami pertumbuhan. Melemahnyaperekonomian nasional tidak berpengaruh secara signifikan terhadap kinerjaindustri kosmetik dan keperluan rumah tangga nasional.Tingginya tingkat permintaan terhadap produk kosmetik dan keperluan rumah tangga membuat 
industri ini mengalami pertumbuhan hingga 15\% (KEMENPRIN, berita industri 2016).

Perusahaan dalam memperoleh keuntungan yang diharapkan membutuhkan dana yang dijadikan sebagai modal. Modal yang dibutuhkan perusahaan dapat berasal dari luar maupun dari dalam perusahaan. Perusahaan yang menggunakan lebih banyak hutang berarti memperbesar risiko yang ditanggung pemegang saham serta memperbesar tingkat pengembalian investasi (Brigham dan Houston, 2001). Semakin banyak hutang perusahaan, maka akan semakin menurunkan likuiditas perusahaan. Perusahaan yang memiliki likuiditas kecil membuat nilai perusahaan di mata investor kurang baik, sebaliknya perusahaan yang memiliki tingkat likuiditas tinggi maka akan semakin baik, karena perusahaan mampuuntuk membayar hutangnya tepat waktu. Rasio likuiditas merupakan rasio yang menggambarkan kumpulan kemampuan perusahaan dalam memenuhi kewajiban jangka pendek (Kasmir, 2012), artinya perusahaan mampu membayar hutang jangka pendeknya pada saat jatuh tempo dengan menggunakan aktiva yang ada terutama aktiva lancar.

Berdasarkan penjelasan di atas, maka penulis tertarik untuk mengajukan penelitian yang berjudul "Pengaruh Struktur Modal, Likuiditas, dan Ukuran Perusahaan Terhadap Kinerja Keuangan Perusahaan Manufaktur Subsektor Keperluan Rumah Tangga Yang Terdaftar Di Bursa Efek Indonesia (BEI) Periode 2014-2018”,

\section{Rumusan Masalah}

Apakah struktur modal, likuiditas, dan ukuran perusahaan berpengaruh terhadap kinerja keuangan perusahaan manufaktur subsektor kosmetik dan keperluan rumah tangga yang terdaftar di BEI periode 2014-2018?

\section{Tujuan dan Manfaat Penelitian}

1. Untuk mengetahui pengaruh struktur modal yang diukur dengan Debt to Equity Ratio (DER) terhadap kinerja keuangan perusahaan (ROE) pada perusahaan manufaktur subsektor keperluan rumah tangga yang terdaftar di BEI.

2. Untuk mengetahui pengaruh likuiditas yang diukur dengan Current Ratio (CR) terhadap kinerja keuangan perusahaan (ROE) pada perusahaan manufaktur subsektor keperluan rumah tangga yang terdaftar di BEI.

3. Untuk mengetahui pengaruh ukuran perusahaan yang dilihat dari total penjualan terhadap kinerja keuangan perusahaan (ROE) pada perusahaan manufaktur subsektor keperluan rumah tangga yang terdaftar di BEI. 
4. Untuk mengetahui pengaruh struktur modal (DER), likuiditas (CR), dan ukuran perusahaan (size) secara bersama-sama terhadap kinerja keuangan perusahaan (ROE) pada perusahaan manufaktur efek subsektor keperluan rumah tangga yang terdaftar di Bursa Efek Indonesia (BEI)

\section{KAJIAN PUSTAKA, KERANGKA PEMIKIRAN DAN HIPOTESIS}

\section{Struktur modal}

Menurut Arifin (2007) struktur modal (capital structure) merupakankombinasi hutang dan ekuitas dalam struktur keuangan jangka panjangperusahaan. Tidak seperti debt ratio atau leverage ratio yang hanyamenggambarkan rasio hutang dan ekuitas pada suatu saat tertentu, struktur modallebih menggambarkan target komposisi hutang dan ekuitas dalam jangka panjangpada suatu perusahaan

Struktur modal dapat diukur dengan beberapa cara, dalam penelitian inistruktur modal dihitung dengan menggunakan debt to equity ratio. Debt to equityratio merupakan salah satu rasio dari solvabilitas atau leverage ratio. Laverageratio mengukur seberapa jauh perusahaan menggunakan hutang (Husnan danPujiastuti, 2006). Menurut Fahmi (2014) leverage ratio mengukur seberapa besarperusahaan dibiayai dengan hutang. Penggunaan hutang yang terlalu tinggi akanmenyebabkan perusahaan kesulitan membayar hutang karena perusahaan akanmasuk dalam katagori extreme leverage (hutang ekstrim) yaitu perusahaanterjebak dalam tingkat hutang yang tinggi dan sulit untuk melepaskan bebanhutang tersebut. Leverage ratio menurut Prabansari dan Kusuma (2005) adalahperbandingan yang dimaksud untuk mengukur seberapa jauh aktiva perusahaandibiayai dengan hutang.

\section{Likuiditas}

Rasio likuiditas (liquidity ratio) digunakan untuk mengukur kemampuanperusahaan untuk memenuhi liabilitas jangka pendeknya. Rasio inimembandingkan liabilitas jangka pendek (atau lancar) dengan aktiva lancar yangtersedia untuk memenuhi liabilitas tersebut. Rasio 2 likuiditas menurut Kasmir(2012) merupakan rasio yang menggambarkan kumpulan kemampuan perusahaandalam memenuhi kewajiban jangka pendeknya, sedangkan menurut Harahap(2015) rasio likuiditas menggambarkan kemampuan perusahaan untuk menyelesaikan kewajiban jangka pendeknya.

\section{Current ratio (CR)}

Salah satu dari rasio likuiditas yang paling umum dan sering digunakanadalah rasio lancar (current ratio). Rasio lancar adalah aset lancar dibagi denganliabilitas jangka pendek. Rasio ini menunjukkan kemampuan perusahaan untukmembayar 
liabilitas jangka pendeknya dengan menggunakan aset lancarnya(Horne dan Wachowicz, 2012). Current ratio menurut Husnan (2013) adalah rasioyang mengukur seberapa jauh aktiva lancar perusahaan bisa dipakai untukmemenuhi kewajiban lancarnya.

\section{Kinerja keuangan}

Sutrisno (2009) menjelaskan pengertian kinerja keuangan perusahaanmerupakan prestasi yang dicapai perusahaan dalam periode tertentu yangmencerminkan tingkat kesehatan perusahaan tersebut. Menurut Fahmi (2011)kinerja keuangan adalah suatu analisis yang dilakukan untuk melihat sejauh manasuatu perusahaan telah melaksanakan dengan menggunakan aturan-aturanpelaksanaan keuangan dengan baik dan benar.

Populasi dan Sampel

Populasi dalam penelitian ini adalah seluruh perusahaan perusahaan sektormanufaktur subsektor keperluan rumah tangga yang terdaftar diBursa Efek Indonesia (BEI). Populasi yang terdapat dalam penelitian ini sebanyak6 (enam) perusahaan. Penentuan sampel menggunakan metode purposivesampling, yaitu penentuan sampel dari populasi yang ada berdasarkan kriteriayang dikehendaki oleh peneliti. Purposive sampling adalah cara mengambilansampel yang disebut pula dengan judgement sampling, yaitu cara pengambilan sampel yang didasarkan pada pertimbangan-pertimbangan tertentu, terutamapertimbangan yang diberikan oleh sekelompok pakar atau expert (Sanusi, 2014). Metode ini dipilih dengan tujuan agar data yang diperoleh sesuai dengan tujuanpenelitian dan juga agar hasil penelitian ini dapat dibandingkan dengan hasilpenelitian sebelumnya karena penelitian sebelumnya menggunakan metode yangsama.

\section{Metode Pengumpulan Data}

Dokumentasi

Pengumpulan data dengan metode dokumentasi adalah metodepengumpulan data dengan mengumpulkan data-data sekunder perusahaanyang akan diteliti. Jenis data yang di gunakan adalah data sekunder berupaannual report, data ini diambil dari laporan keuangan tahunan perusahaanperusahaan yang terdaftar di Bursa Efek Indonesia sektor manufaktursubsektor kosmetik dan keperluan rumah tangga. Data diambil dari situsresmi BEI, yaitu www.idx.co.id

Studi pustaka

Metode studi pustaka digunakan untuk mengambil literatur dari penelitisebelumnya yang berkaitan dengan penelitian ini untuk menambah informasi. Literatur diambil dari jurnal-jurnal, skripsi, buku-buku, daninternet. 


\section{Metode Analisis Data}

\subsubsection{Statistik deskriptif}

Statistik deskriptif (descriptive statistics) yaitu statistik yang menggambarkanfenomena yang menarik penelitian. Statistik deskriptif meliputi transformasi datamentah ke dalam bentuk yang akan memberi informasi untuk menjelaskansekumpulan faktor dalam suatu situasi (Sekaran, 2006). Menurut Ferdinand(2006) statistik deskriptif digunakan untuk memberikan gambaran atau deskripsiempiris atas data yang dikumpulkan dalam penelitian. Pada penelitian ini, statistikdeskriptif dilihat dari rata-rata (mean), maksimum, minimum, dan standar deviasiuntuk mengetahui tingkat rata-rata dan perbedaan dari indikator struktur modal,likuiditas, ukuran perusahaan dan kinerja keuangan perusahaan manufaktur

subsektor kosmetik dan keperluan rumah tangga yang terdaftar di BEI.

Uji Normalitas

Uji normalitas bertujuan untuk menguji apakah dalam model regresi, variabeldependen dan variabel independen mempunyai distribusi normal atau tidak.Model regresi yang baik adalah yang memiliki distribusi data normal ataumendekati normal. Pengujian normalitas data, dapat menggunakan metode OneSample Kolmogorov-Smirnov. Uji Kolmogorov-Smirnov digunakan untuk ujistatistik apakah sampel pada penelitian ini terdistribusi normal atau tidak. UjiKolmogorov-Smirnov memiliki ketentuan jika nilai signifikansiKolmogorovSmirnov lebih besar dari nilai signifikansi yang ditetapkan maka data terdistribusisecara normal. Residual berdistribusi normal jika memiliki nilai signifikansi $\geq 0,05$ (Gozali, 2011) 


\section{Uji multikolinieritas}

Uji multikolinearitas dilakukan untuk mengetahui apakah model regresiUntuk mendeteksi ada tidaknya multikoliniearitas dalam model regresidiilakukan dengan melihat nilai toleran dan nilai Variance Inflation Factor (VIF)yang dapat dilihat dari output SPSS, dengan hasil sebagai berikut:c 1. Jika nilai tolerance $>10$ persen dan nilai VIF $<10$, maka dapatdisimpulkan bahwa tidak ada multikolineritas antar variabel bebas dalammodel regresi. 2. Jika nilai tolerance $<10$ persen dan nilai VIF $>10$, maka dapatdisimpulkan bahwa ada multikolinaeritas antar variabel bebas dalammodel regresi.

\section{Uji heteroskedatisitas}

Heteroskedastisitas adalah varian residual yang tidak konstan pada regresisehingga tingkat akurasi hasil penelitian menjadi kurang. Heteroskedastisitasdapat diartikan juga sebagai ketidak samaan variasi variabel pada semuapengamatan, dan kesalahan yang terjadi memperlihatkan hubungan yangsistematis sesuai dengan besarnya satu atau lebih variabel bebas sehinggakesalahan tersebut tidak random. Uji heteroskedastisitas bertujuan untuk mengujiapakah dalam model regresi terjadi ketidaksamaan variance dari residual satu

pengamatan ke pengamatan lain. Ada beberapa cara yang dapat dilakukan untuk melakukan uji heterokedastisitas, yaitu uji grafik plot, uji glejser, dan uji white.

\section{Kesimpulan dan Saran}

Berdasarkan hipotesis, analisis pengujian data, dan hasil pembahasan padabab sebelumnya penelitian ini bertujuan untuk menganalisis pengaruh strukturmodal, likuiditas, dan ukuran perusahaan terhadap kinerja keuangan perusahaan manufaktur subsektor kosmetik dan keperluan rumah tangga yang terdaftar di Bursa Efek Indonesia (BEI) periode 2014-2018, maka dapat disimpulkan bahwa : 1. Hipotesis penelitian $\left(\mathrm{H}_{1}\right)$

Berdasarkan hasil penelitian variabel struktur modal yang diukur dengandebt to equity ratio (DER) berpengaruh positif dan signifikan terhadapkinerja keuangan 
yang diukur dengan return on equity (ROE) padaperusahaan manufaktur subsektor kosmetik dan keperluan rumah tanggayang terdaftar di BEI periode 2008-2015 dengan koefisien regresi 0,43 atau43\% dan tingkat kepercayaan 95\%, yang artinya semakin besar DER makaROE juga akan semakin besar. Hasil pengujian ini menunjukkan hipotesispenelitian $\mathrm{H}_{1}$ yaitu: Debt to Equity Ratio (DER) berpengaruh terhadapReturn On Equity (ROE) diterima.

\section{Hipotesis penelitian $\left(\mathrm{H}_{2}\right)$}

Variabel likuiditas (current ratio/terhadap ROE pada perusahaan manufaktur subsektor kosmetik dankeperluan rumah tangga yang terdaftar di BEI periode 2008-2015 denganhasil koefisien determinasi 0,12 atau $1,2 \%$ dan tingkat signifikansi $\geq 0,05$ dengan tingkat kepercayaan 95\%. Hasil pengujian ini menunjukkanhipotesis penelitian $\mathrm{H}_{2}$ yaitu: Current Ratio (CR) berpengaruh terhadapReturn On Equity (ROE) ditolak.

Hipoteisis penelitian $\left(\mathrm{H}_{3}\right)$

Hasil penelitian menunjukkan bahwa hipotesis $\mathrm{H}_{3}$, yaitu ukuran perusahaan(size) berpengaruh positif terhadap return on equity (ROE) pada perusahaanmanufaktur subsektor kosmetik dan keperluan rumah tangga yang terdaftardi BEI periode 2008-2015 dapat diterima, yang artinya ada pengaruh positifantara ukuran perusahaan yang diukur dengan Ln total penjualan terhadapROE. Semakin besar size perusahaan maka ROE juga akan semakinmeningkat. Hasil signifikansi positif dilihat dari koefisien regresi sebesar10,110 dengan tingkat kepercayaan $95 \%$.

\section{Hipotesis penelitian $\left(\mathrm{H}_{4}\right)$}

Secara simultan atau bersama-sama variabel struktur modal (DER),likuiditas (CR), dan ukuran perusahaan (size) berpengaruh positif dansignifikan terhadap kinerja keuangan (ROE) pada perusahaan manufaktursubsektor kosmetik dan keperluan rumah tangga yang terdaftar di BEIperiode 2008-2015 dengan hasil 
perhitungan uji $\mathrm{F}$ sebesar 162,005 dantingkat signifikansi 0,000. Hasil pengujian ini menunjukkan bahwa hipotesispenelitian $\left(\mathrm{H}_{4}\right)$ diterima.

Berdasarkan hasil penelitian dapat disimpulkan bahwa variabel strukturmodal berpengaruh positif terhadap kinerja keuangan perusahaan. Sesuaidengan teori trade-off yang menyatakan perusahaan memanfaatkanpendanaan dengan hutang untuk mengurangi pajak, sehingga akanmeningkatkan laba. Variabel ukuran perusahaan menjadi variabel yangpaling dominan berpengaruh terhadap kinerja keuangan perusahaan, yangartinya apabila penjualan meningkat maka laba perusahaan juga akan ikutmeningkat. Sesuai dengan pecking order theory bahwa perusahaan lebihmenyukai sumber dana internal seperti laba, sedangkan variabel likuiditastidak memiliki pengaruh terhadap kinerja keuangan pada industri kosmetikdan keperluan rumah tangga

\section{DAFTAR PUSTAKA}

Arifin, Zaenal. 2007. Teori Keuangan \& Pasar Modal. Edisi 1. Yogyakarta. EKONISIA.

Brigham, Eugene F. dan Houston, Joel F. 2001. Manajemen Keuangan. Penerjemah Hermawan Wibowo. Edisi Kedelapan. Buku II. Edisi Indonesia. Jakarta: Penerbit Erlangga

Fachrudin, Khaira Amalia. 2011. "Analisis Pengaruh Struktur Modal, Ukuran Perusahaan, dan Agency Cost Terhadap Kinerja Perusahaan". Jurnal Akuntansi dan Keuangan. Edisi Mei 2011. Volume 13 No. 1. pp. 37-46

Harahap, Sofyan Syafri. 2015. Analisis Kritis atas Laporan Keuangan. Cetakan ke-12. Jakarta: PT Raja Grafindo Pustaka Utama

Kasmir. 2012. Analisis Laporan Keuangan. Jakarta: PT Rajagrafindo Persada.

Sundjaja, Ridwan S, dkk. 2013. Manajemen Keuangan 1. Edisi 8. Jakarta: Literata Lintas Media.

Syamsuddin, Lukman. 2007. Manajemen Keuangan Perusahaan: Konsep Aplikasi dalam Perencanaan, Pengawasan, dan Pengambilan Keputusan. Edisi

Baru. Jakarta: PT Raja Grafindo Persada. 